\title{
Liver fatty acid-binding protein may be a useful marker for non-alcoholic fatty liver disease but obesity is a major concern
}

\author{
Alpaslan Tanoglu · Yavuz Beyazit
}

Received: 7 January 2015 / Accepted: 7 January 2016 / Published online: 1 February 2016

(C) Springer-Verlag Wien 2016

\section{Dear editor,}

In their relevant study, Akbal et al. [1] demonstrate that liver fatty acid-binding protein (L-FABP) can be used as a diagnostic marker for non-alcoholic fatty liver disease (NAFLD). Moreover, the authors point out that L-FABP correlates with conventional liver function tests. We think that several issues require clarification and further discussion regarding this study, because of three potential confounding variables that were underemphasized by the authors.

First of all, small sample size is a major concern for the current study. Therefore, these findings regarding the relationship between L-FABP and NAFLD may not be generalized to the broader community based on this study alone. Secondly, ultrasonography based diagnosis of NAFLD is another concern about this study. Liver biopsy is known to be the gold standard in the diagnosis and grading of NAFLD [2,3]. Thus, it would have been more useful if biopsy diagnosed patients with NAFLD were included in the study. Thirdly, a major methodological concern also exists regarding this article. Previously, it has been shown [4] that liver fatty acid-binding protein levels in obese subjects were significantly higher than those from normal-weighted subjects. In other words, elevated body mass index (BMI) levels influence the L-FABP levels. However, the BMI of NAFLD patients seems to be statistically higher than controls in this study, which could be the reason for elevated FABP. Contrary to the authors' suggestions, we think that elevated L-FABP levels could also be related to the higher BMI of NAFLD patients.

In conclusion, higher L-FABP levels can be seen in NAFLD patients, but no definitive conclusions can be made without excluding critical variables that could affect L-FABP levels.

\section{Conflict of interest}

The authors have no conflict of interest to declare.

\section{References}

1. Akbal E, Koçak E, Akyürek O, Köklü S, Batgi H, Senes M. Liver fatty acid-binding protein as a diagnostic marker for non-alcoholic fatty liver disease. Wien Klin Wochenschr. 2014. [Epub ahead of print].

2. Kobyliak N, Abenavoli L. The role of liver biopsy to assess non-alcoholic fatty liver disease. Rev Recent Clin Trials. 2014;9:159-69.

3. Özenirler S, Degertekin CK, Erkan G, Elbeğ Ş, Tuncer C, Kandilc U, et al. Serum liver fatty acid binding protein shows good correlation with liver histology in NASH. Hepatogastroenterology. 2013;60:1095-100.

4. Shi J, Zhang Y, Gu W, Cui B, Xu M, Yan Q, et al. Serum liver fatty acid binding protein levels correlate positively with obesity and insulin resistance in Chinese young adults. PLoS One. 2012;7:e48777.

\footnotetext{
Dr. A. Tanoglu, MD ( $\bowtie)$

Department of Gastroenterology,

GATA Haydarpasa Training Hospital,

34668 Uskudar/Istanbul, Turkey

e-mail: alpaslantanoglu@yahoo.com

Y. Beyazit, MD

Department of Gastroenterology,

Canakkale State Hospital,

Canakkale, Turkey
} 